\author{
ACTA MYCOLOGICA \\ Vol. 43 (2): 139-142 \\ 2008
}

\title{
Recent records of hypogeous fungi in Greece
}

\author{
STEPHANOS DIAMANDIS and CHARIKLEIA PERLEROU
}

NAGREF-Forest Research Institute

GR-570 06 Vassilika, Thessaloniki, diamandi@fri.gr

\begin{abstract}
Diamandis S., Perlerou Ch.: Recent records of hypogeous fungi in Greece. Acta Mycol. 43 (2): 139-142, 2008.

Uncertainty among Greek farmers who are in search of new and profitable crops has increased interest in truffle cultivation. Recent research has come up with 23 taxa of hypogeous fungi new for Greece including gastronomically valuable species. Natural ecosystems of Quercus pubescens, $Q$. frainetto, $Q$. ilex and $Q$. coccifera seem to be rich in hypogeous species. Ecosystems with Corylus avellana, Carpinus betulus, Mediterranean pines and even poplar plantations were found to also host hypogeous fungi. These records, supported by historical information about the existence of truffles in Greece, seem to be encouraging hints for systematic truffle cultivation.
\end{abstract}

Key words: hypogeous fungi, truffles, Greece

\section{INTRODUCTION}

Hypogeous fungi and truffles in particular have been known in Greece since antiquity. Theophrastus (372-287 B.C.) and Dioscurides in the $1^{\text {st }}$ Century A.D. refer widely to truffles which then were known by the name hydnum, plural hydna. Theophrastus in Plants writes "they grow spontaneously in the ground, chiefly in sandy places especially after the autumn rains come with severe thunderstorms. They are not perennial, but come up every year, and the proper time to use them is in the spring". Diocles of Carystus ( $4^{\text {th }}$ century B.C.), in Book I of his Health, says: "Wild vegetables fit to boil are the beet, mallow, sorrel, nettle, orach, iris-bulbs, truffles, and mushrooms."

Romans considered Greek truffles to be of high culinary quality and according to the Italian medical doctor, Bartolomeo Platina (1400 A.D.), the best truffles were those of Africa, Syria, Greece and Libya. However, as a matter of fact, lack of recent scientific information on hypogeous fungi left Greece behind its neighboring countries in truffle cultivation as a profitable agricultural activity.

Research was triggered by the fact that Greek farmers look desperately for profitable new crops in sight of the new EU Common Agricultural Policy, which by 2013 cuts down subsidies for cotton, tobacco and numerous other traditional 
Mediterranean products. Investigations were carried out in 2006-2007 mainly in $\mathrm{N}$. Greece in calcareous, poor, mountainous sites in the altitudinal zone of 170-700 $\mathrm{m}$. Trained truffle dogs were used in a variety of forest ecosystems and at different seasons. Site description including coordinates were kept for each searched area. As the work is still in progress and the collected data incomplete, no comments are made here about the frequency of the species recorded.

The objectives of the current work were: a) to search for hypogeous fungi, b) to confirm whether or not there are indigenous species of high gastronomic and consequently commercial value, and c) to study their habitats in order to assist the successful establishment of truffle plantations in Greece.

\section{RECORDED TAXA}

Balsamia vulgaris Vittad.

It was found repeatedly under Quercus pubescens in the autumn and early winter.

Elaphomyces muricatus Fr.

It was collected in natural mixed ecosystems with dominant Carpinus orientalis, in natural forests of Pinus halepensis and plantations of $P$. brutia. Carpophores appear in the autumn (Diamandis 2007).

Gautieria graveolens Vittad. var. graveolens

It was recorded only once in natural forests of Quercus frainetto (Konstantinides 2006).

\section{Gautieria morchellaeformis Vittad.}

It was found under Quercus ilex (Konstantinides 2006) while we found it in natural forests of black pine (Pinus nigra).

Genea fragrans (Wallroth) Paoletti

It was found under Quercus pubescens in calcareous soils at $350 \mathrm{~m}$. Its separation from the similar species G. verrucosa is based on its longer asci and bigger and ornamented ascospores (Montecchi, Sarasini 2000).

Hydnocystis clausa (Tul. \& C.Tul.) Ceruti

It grows under umbrella pine (Pinus pinea) in warm, sandy areas. It was detected by truffle dogs at the end of winter (Fig. 1). It was found in Peloponesse, S. Greece under old growth forest.

Hymenogaster bulliardii Vittad.

It occurs in natural forests of Quercus frainetto and $Q$. ilex in calcareous soils (Konstantinides 2006).

Hysterangium calcareum Hesse

It was found along the banks of a mountain stream under hazelnut (Corylus avellana) and beech (Fagus sylvatica) (Konstantinides 2006).

Melanogaster broomeanus Berk. ex Tul. \& C. Tul.

It was collected near hazelnut trees (Corylus avellana) in late autumn.

Melanogaster variegatus (Berk.) Zeller \& Dodge

It occurs as mycorrhizal with Cistus incanus in coastal Mediterranean ecosystems at low altitudes. It was also found in large numbers under Quercus ilex in a 
truffle plantation along with Tuber melanosporum. This fungus has the reputation of occurring in xerophilous habitats.

Melanogaster vittadinii Soehner et Knapp

It was found in natural forests of Quercus frainetto (Konstantinides 2006). We also found it in dense ecosystems of $Q$. coccifera.

Tuber aestivum Vittad.

It grows in plantations of Pinus brutia and natural ecosystems of Quercus coccifera, Q. pubescens, Paliurus spina-christi, Cistus spp. at 150-450 m a.s.1. Carpophores are produced in large numbers from May to July. Its abundance, gastronomic importance and high market value makes it favourable to truffle hunters (Diamandis 2007) (Fig. 2).

Tuber borchii Vittad.

It occurs widely almost everywhere in Greece in Mediterranean shrub ecosystems mixed with Pinus brutia and in slightly acidic soils at low altitudes (100-400 m a.s.l.). It was also collected in poplar plantations. This is a commercial species too and achieves reasonable market prices in Italy and other countries (Diamandis 2007).

Tuber brumale Vittad.

This winter truffle occurs in natural forests of Quercus pubescens, $Q$. frainetto and Fagus sylvatica at altitudes between 500-700 m a. s. 1. (Diamandis 2007).

Tuber brumale Vittad. f. moschatum (Ferry) Mont. \& Lazzari

Carpophores were collected under Quercus pubescens. Their main characteristic is the much stronger and pleasant aroma when compared to carpophores of $T$. brumale (Diamandis 2007).

Tuber excavatum Vittad.

It was recorded in natural mixed forests of Quercus pubescens, Q. coccifera and Carpinus orientalis.

Tuber melanosporum Vittad.

So far it was found only in natural forests of Quercus pubescens which in Greece occupy the zone $200-450 \mathrm{~m}$ a.s.1. This species, being the most valuable of all black truffles, is now being investigated in several habitats in order to understand its mycorrhizal associates in Greece and map its geographical distribution. Significant truffle production has been recorded in newly established plantations of Quercus pubescens, $Q$. ilex and Corylus avellana showing the potential importance of truffle cultivation in Greece (Diamandis 2007).

Tuber mesentericum Vittad.

It was recorded in natural forests of Quercus pubescens in late autumn and early winter (Diamandis 2007).

Tuber panniferum Tul.\& C. Tul.

It was found under Quercus ilex. Its carpophores are easy to identify in the field because of their chestnut-brown and hairy exoperidium (Diamandis 2007) (Fig. 3).

Tuber puberulum Berk. \& Broome It was found in natural forests of Quercus pubescens and $Q$. frainetto at $650 \mathrm{~m}$ a. s. 1. (Diamandis 2007).

Tuber rufum Pico: Fr. var. apiculatum Fischer

Carpophores were found in the autumn in mixed ecosystems of Quercus coccifera and $Q$. pubescens. 
Tuber rufum Pico: Fr. var. nitidum (Vittad.) Mont. \& Lazzari

It was found in the autumn in mixed ecosystems of Quercus coccifera and Q. pubescens.

\section{Tuber rufum Pico: Fr. var. rufum}

It occurs in natural mixed forests of Quercus pubescens, Q. coccifera and Carpinus orientalis (Diamandis 2007).

\section{DISCUSSION}

Recent efforts for the detection of hypogeous fungi revealed 23 taxa in a variety of forest ecosystems and Mediterranean pine plantations. Several of them are also encountered in other Mediterranean countries such as Italy (Montecchi, Sarasini 2000), Spain (Moreno Arroyo et al. 2005) and Serbia (Glamočlija et al. 1997).

The discovery of such a significant number of taxa enforces the increasing belief that Greece, despite its warm and dry climate, holds a particularly rich fungal biodiversity. Furthermore, the collection of indigenous truffles of the gastronomically valuable species Tuber melanosporum, T. aestivum, T. brumale and T. borchii promotes the introduction of truffle cultivation in mountainous areas where farmers do not have much choice in what to grow. Tuber aestivum in particular was found fruiting in rocky sites where nobody would expect the existence of truffles. Calcareous rocks usually have vertical cracks where Quercus coccifera, an extremely hardy species of oak, can extend its long roots. While such roots host mycorrhizal association, truffles have no other space to grow but at the tops of the cracks (Fig. 4).

A large part of the country is covered with calcareous soils while suitable mycorrhizal tree species such as Quercus pubescens, Q. ilex, Q. coccifera, Q. frainetto, Q. cerris, Corylus avellana, Carpinus orientalis and C. betulus, Mediterranean pines like Pinus halepensis, $P$. brutia and $P$. pinea occur naturally and widely in Greece. Truffle cultivation may be possible in a wide range of habitats with numerous hosttrees rendering it as a wise alternative and an important future agricultural activity in poor, mountainous sites.

Acknowledgements. We would like to deeply thank our enthusiastic friends Panos Panagiotides, Giuseppe Donatiello, Nick Athanasiades, John Zervas and Marios Arcoulis and Christos Chrysopoulos, all truffle hunters, for sending in specimens with the relevant information. Without their contribution this work could not have been achieved.

\section{REFERENCES}

Diamandis S. 2007. Recent records of hypogeous fungi in Greece. XV CEM, St. Petersburg, 16-21 Sept., Summary in Proceedings: 118.

Glamočlija J., Vujičić R., Vukojević J. 1997. Evidence of truffles in Serbia. Mycotaxon 65: 211-222.

Konstantinides G. (ed.). 2006. 1000 Mushrooms and Toadstools of W. Macedonia. Mycological Society of W. Macedonia (MSWM), Kastoria, 525 pp.

Montecchi A., Sarasini M. 2000. Funghi ipogei d' Europa. Assoc. Micologia Bresadola, Trento, 714 pp.

Moreno Arroyo B., Gómez Fernandez J., Pulido Calmaestra E. 2005. Tesoros de nuestro montes. Trufas de Andalucía. Consejería de Medio Ambiente, Junta de Andalucía, Córdoba, 352 pp. 


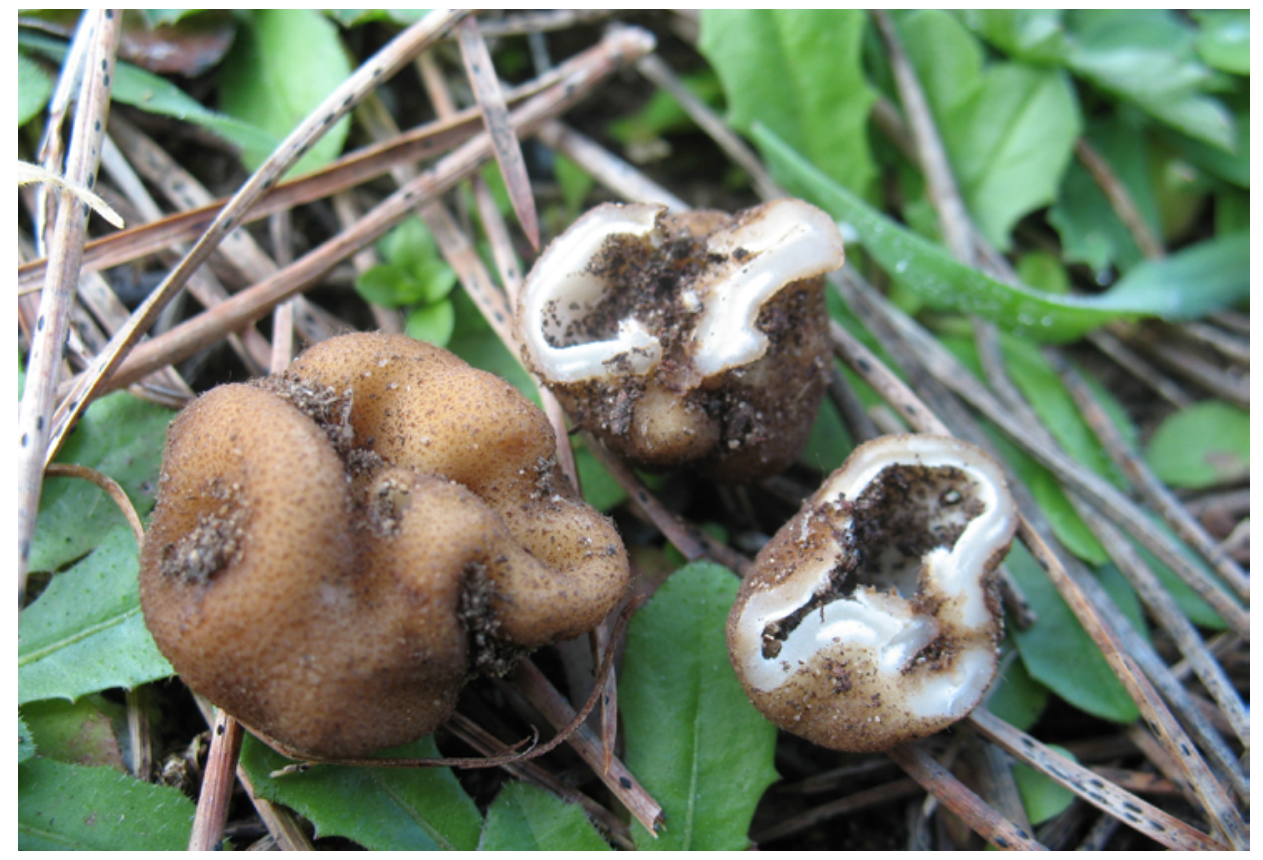

Fig. 1. Hydnocystis clausa found under Pinus pinea in warm, sandy areas.



Fig. 2. An impressive collection of Tuber aestivum collected in the morning of July 212007. 




Fig. 3. Tuber panniferum with its chestnut-brown and hairy exoperidium - secure base for identification in the field.

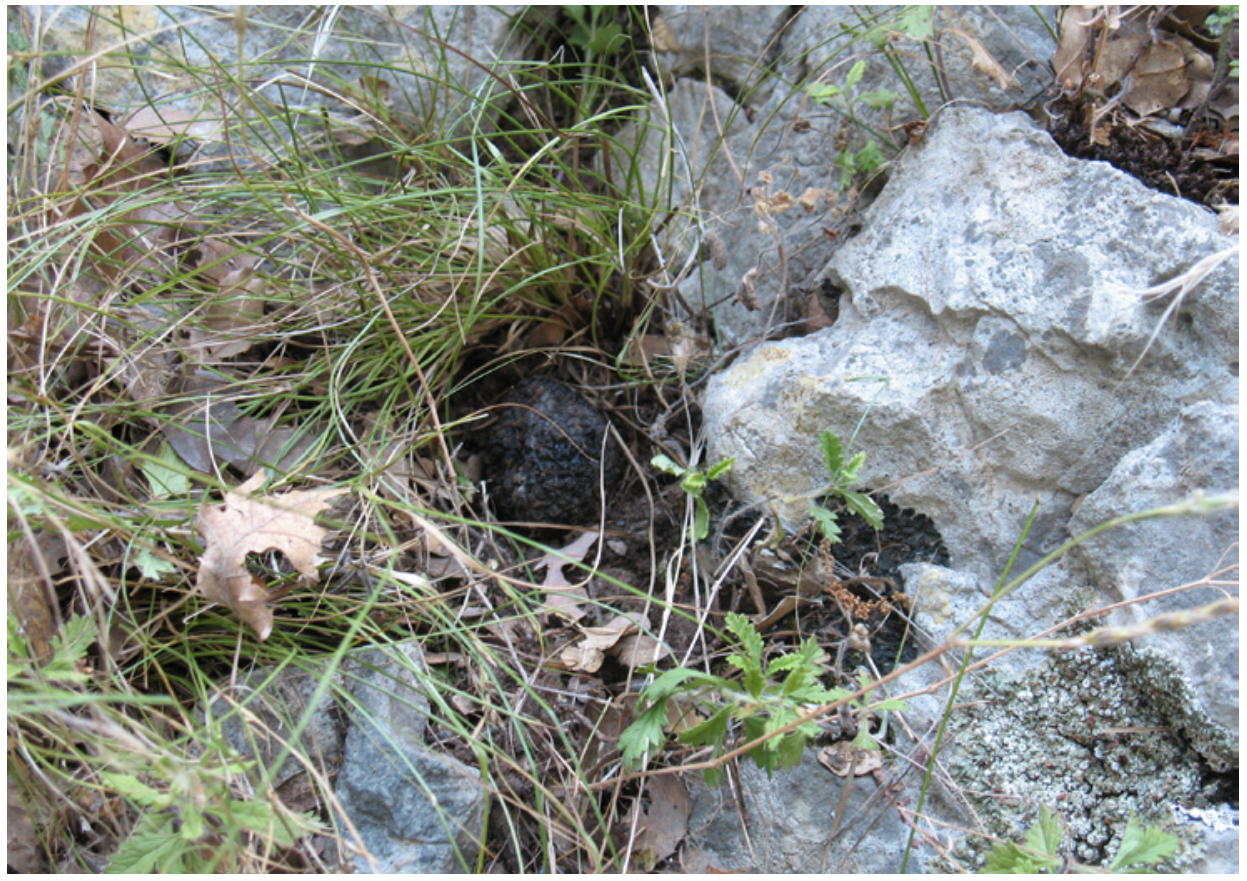

Fig. 4. Summer truffle in association with Quercus coccifera fruiting at the top of crack, surrounded by calcareous rock. 